Journey through a Portion of South-Eastern Tibet and the Mishmi Hills Author(s): F. M. Bailey

Source: The Geographical Journal, Vol. 39, No. 4 (Apr., 1912), pp. 334-347

Published by: geographicalj

Stable URL: http://www.jstor.org/stable/1778662

Accessed: 20-06-2016 17:17 UTC

Your use of the JSTOR archive indicates your acceptance of the Terms \& Conditions of Use, available at

http://about.jstor.org/terms

JSTOR is a not-for-profit service that helps scholars, researchers, and students discover, use, and build upon a wide range of content in a trusted digital archive. We use information technology and tools to increase productivity and facilitate new forms of scholarship. For more information about JSTOR, please contact support@jstor.org.

The Royal Geographical Society (with the Institute of British Geographers), Wiley are collaborating with JSTOR to digitize, preserve and extend access to The Geographical Journal 
otherwise, must feel themselves under a debt of gratitude to Mr. Smith for work he has done.

Major Darwin: I know nothing about New Guinea myself, but, as you know, I have been to many lectures in this building. There are three qualities every explorer must have: he must have personal courage, he must have forethought, and he must have the aptitude of making friends with the natives. I think our lecturer has been conspicuous in all these three qualities. Only one other thing is necessary, and that is a bit of good luck. Whether to say he had good luck or bad luck, I do not know; he had extremely bad luck in certain respects, but he had the good luck that he was not drowned, and on that I think we all congratulate him. He evidently ran very great risks. I am sure I may, in the name of everybody present, congratulate him on his success, and thank him for his most interesting lecture.

\title{
JOURNEY THROUGH A PORTION OF SOUTH-EASTERN TIBET AND THE MISHMI HILLS."
}

\author{
By Captain F. M. BAILEY.
}

THE following account of a journey through a small unsurveyed portion of south-eastern Tibet and the Mishmi hills may be of interest in view of the military and political measures recently taken in consequence of the murder of Mr. Williamson and Dr. Gregorson by the Abors.

I travelled out by the Siberian railway, and after being detained for a week in quarantine, on account of the plague which was raging in Manchuria, reached Peking on March 8, 1911. Having spent a week in the capital and obtained a passport, I took the train to Hankau, where it was necessary to wait for some days before an up-river steamer left for Ichang. From Ichang I passed up through the Yangtse gorges, about which so much has been written, in company with Mr. Hill of the Chinese Customs, who shared a house-boat with me for this part of the journey; unfortunately, we were wrecked in one of the rapids, and obliged to pass the night in the open. On reaching Wan-Hsien, I spent two days with Mr. and Mrs. Ortolani, of the Imperial Post Office, while making preparations for my 400-mile journey to Chengtu. At Chengtu I enjoyed the hospitality of Mr. Wilkinson, H.B.M.'s Consul-General, for a few days before continuing my journey. At Ya-chou Fu I called on one of the large firms engaged in the Tibetan tea trade, and saw coarse tea-bricks being made. At Ta-chien-lu, where the first Tibetans were met with, I sent back a useless Chinese servant who had accompanied me from Peking, and took in his place a Tibetan, who remained with me until I was about to enter the Mishmi country.

From Ta-chien-lu I made an excursion in search of Takin (Budorcas taxicolor) to a place some 15 miles to the south, crossing a pass called Boi La (13,240 feet), which on May 14 was covered with snow about a foot deep. From here some very distant snow mountains were visible to the

* Map, p. 420 . 
south and to the south-west, the latter range being somewhat the nearer of the two. Below the pass I saw some magnificent yellow poppies, one of which measured $6 \frac{1}{2}$ inches in diameter. I was unsuccessful in my search for Takin, though many tracks some months old were visible. On this trip I saw gamo birds of many kinds: snipe, woodcock, and pheasants of five variêties, as well as partridges and two varieties of snowcock; * there was also a large bird, called Cha na in Tibetan and Huo tan chi in Chinese, which lives at the snow-line, but $I$ was unable to get a view of it and could not shoot a specimen. Besides tracks of Takin, I found those of serow and musk-deer, and close to Ta-chien-lu I saw three stags which had been taken in the neighbourhood and were kept in captivity. It was said that there were burhel (Ovis nahura) on the Boi La To (pass), but, though I spent a day in the search, I did not succeed in finding them. I left Ta-chien-lu finally on May 19, and in five marches reached Ho-kou, or Nyachuka as it is called in Tibetan, where I found a French engineer, M. Kerihuel, engaged in building a suspension bridge over the Yalung river. The next place of importance on the road was Litang, where, by invitation, I stayed in the large lamasery. On June 2 I arrived at Batang, where I was the guest of Mr. and Mrs. Edgar, of the China Inland Mission; and here I was able to obtain cash from a merchant for a cheque on Shanghai.

In company with Mr. Edgar I left Batang on June 6, and was fortunate in having as a companion a man who is not only a keen traveller and observer but has a thorough knowledge of both the Chinese and the Tibetan languages, and whose familiarity with the conditions on this frontier is unsurpassed.

Our first objective was Yen-ching on the Mekong. In some villages on the road we visited schools in which Tibetan children were being tanght by Chinese schoolmasters. Such sshools have been opened wherever twenty pupils can be collected, and attendance is compulsory for children living near them. Outside the school-house were some simple gymnastic appliances, and a time-table with a list of rules was posted on the door. The subjects taught were geography, history, literature, reading, Chinese, recitation, arithmetic, hygiene, drawing, singing, drill, and science; while the rules for conduct in school were the following: "Don't whisper; don't eat; don't fight; don't speak Tibetan; don't recite 'om mani padme hum' or other prayers ; don't carry knives; don't be dirty; don't dirty the desks." Boys and girls were in separate class-rooms, and the ages of the pupils, who were all doing the same work, varied between four years and twenty; they worked for five hours a day on six days a week.

Chinese influence is making itself felt to a considerable extent in the borderland, as is evidenced by these schools. An attempt is also being made to change the Tibetan names of places and to substitute Chinese names; these latter are in some cases a translation of the Tibetan word,

\footnotetext{
* See footnote $(*)$ at the end.
} 
but sometimes they are merely a rough transliteration. The people are bound to take Chinese personal names, which so far are only being used by the Chinese in the law courts, but it is hoped that, eventually, they may entirely supplant the Tibetan ones. A list of suitable Chinese names has been drawn up, and each Tibetan can choose whichever of them takes his fancy.

On passing Pamutang a few days after leaving Batang, we made a slight détour and crossed the Tibetan frontier by the Ning Ching Shan or Po La, a pass where the Tibetans used to maintain a guard of soldiers. From this pass we saw three distant snow-peaks to the south-west. The pass being unoccupied, we went down to the village of Lanteng (or Lhamdun), where we found a party of Chinese soldiers on the march from Chiamdo. We boiled a thermometer here, and obtained an altitude of 12,727 feet. We recrossed the frontier into China the same day. On June 10 we crossed the Kia La (14,894 feet), from which pass we had a view of the hills across the Mekong, but the top of the range was in cloud. Opposite to us we could see the lamasery of La Gong, approached by the very steep zigzag path up which we were to travel the next day. It was late when we reached Yen-ching, and as we were anxious to cross the bridge at once, we passed the town on our left hand, and descended through the steep valley which separates the plateau of Yen-ching from that of Yerkalo, where there is a French mission station. On reaching the bank of the Mekong, we went a few hundred yards down stream to the rope bridge, which we crossed, and then put up in the village of Jada close to the salt wells. The river was swift, very muddy, and of a reddish colour. As the result of a hypsometrical observation, we found the altitude of the Mekong at the bridge to be 7300 feet. Yen-ching is known in Tibetan as Tsaka, both names indicating that salt is found here. The next morning we went to see the wells. The brine is collected in circular pools about 2 feet deep and 3 or 4 yards in diameter. From these it is taken in birch bark buckets and poured into other and shallower pools underneath drying pans inade of earth spread on wooden platforms, which in the distance look like the flat roofs of a large village. Here it is left till, some of the water having evaporated, it becomes stronger. This brine is then poured into the drying pans. The sun beating upon these evaporates all the water, leaving a thin layer of white salt, which is then swept up with a broom; but a good deal of red earth from the pans is mixed with it, and this gives the salt a dirty reddish appearance. It was at this bridge that Major Javis and his companions were turned back in 1900; the lamas fired on the party and eventually cut the rope bridge. These hostile monks came from the lamasery of La Gong, which we passed through the next day. It had been sacked by the Chinese in 1907 , and at the time of our visit was in charge of a small guard of Chinese soldiers.

Having successfully passed Yen-ching, we decided to make for Menkong, on the Salween. We left the Mekong on June 11. On our second 
day's march we crossed the watershed between the Mekong and the Salween at the Beda La (15,209 feet). There was aconite on the pass, and our transport ponies were therefore muzzled, but we passed an unfortunate man whose pony had eaten the poisonous plant and was dying. He begged us to help him, but we could do nothing, and later in the day he overtook us, his animal having died.

There are said to be stags in the forest near here, but I saw only two gooral. The road up the Beda La was through a forest of fir and pine in which were many beautiful rhododendrons, the lower ones had mauve flowers, while higher up the flowers were white; there were also apricot trees bearing unripe fruit. After crossing the pass, we stopped in the large village of Petu, which M. Bacot had previously visited. This village, with a few outlying farms, has about one hundred inhabitants, besides a lamasery of fifty monks. Our small room was invaded by a friendly crowd of both monks and laymen, to whom Mr. Edgar gave tracts which those able to read devoured with great interest; they frequently tie them along with Tibetan prayers to bridges, or to trees near water or their houses. The women wear a quantity of cheap jewellery. The houses in this neighbourhood are roofed with pine shingles kept in position by heary stones, while the houses at Yen-ching, those at Wabo further down the Drayul $\mathrm{Chu}$, and also those in the Salween valley at Menkong, have the usual flat Tibetan terraced roofs. The Drayul Cha flows past the Yenchin village; it was crossed by A. K. at Drayul Gompa, some three days' journey further north, and he describes it as being 60 paces wide and 3 feet deep. At Petu it cannot be more than 30 yards wide, and this is also the width at a brilge 3 miles further down-stream, but the depth must be considerably more than 3 feet. This river, as we shall see, performs some wonderful geographical gymnastics before it finally falls into the Salween. Like all rivers of any size in this part of the world, it receives a different name every few miles. At Petu the soil yields two crops a year.

After leaving Petu, we crossed a pass, the Tong La (10,797 feet), only to find ourselves again in the valley of the Drayul Chu, which makes a long bend to the south, and again a smaller loop which we could see in front of us. From the Tong La, distant snows were visible to the south and southwest. Before reaching the village of Wabo, we could see the junction of the Drayul Chu with that of the Salween, though we could not see the actual streams at the bottom of the deep valleys. The country here has a bare, arid appearance, but the tops of the hills show signs of a damper climate, being covered with fir and pine forest; lower down is a thick belt of prickly oak, and below that again a small thorny scrub. There are many villages in which crops of barley were being cut, water being brought from the hills in log troughs. The hills are very steep. At the point where we left the Drayul Chu the river issues from a precipitous gorge, and turns sharply to the north. At the village of $\mathrm{Ke}$, a few miles from this bend, it is about 30 yards wide, and 7480 feet above 
sea-level. I obtained a specimen of a snake ${ }^{*}$ near the village of Ke. On leaving the Drayul Chu we crossed the Tondu La (11,240 feet). As we ascended, we passed through the damper zone, where we found the dry-looking shrubs giving place to firs, pines, birches, and rhododendrons, while the ground below them was carpeted with ferns. Our view from the pass to the north was interrupted by the forest through which we had just passed, but that to the south was very striking. The Salween could be seen flowing almost due south, hemmed in by high hills, bare at the base but with a belt of forest higher up, while on the summits were patches of snow with an occasional upstanding snow peak. Spurs came down from the ranges on either side, and the river twisted among these. A few villages could be seen on the banks of the Salween, and the valley running to the river from the pass on which we were standing was well cultivated. After descending steeply from the pass, we reached the village of Lonbo, where we spent the night. The people here were thrashing corn with flails. The next day we were obliged to make a small diversion from the main road to Menkong in order to change our transport animals at the village of Trana. At this point the Salween flows west, but at Trana it takes a turn to the south. The hills are precipitous, with scanty dry vegetation, among which a cactus-like plant, with an orange-coloured flower, was conspicuous. $\dagger$ The Salween is a swift, muddy river, very similar to the Mekong at Yen-ching. We crossed by a rope bridge, and found the altitude of the river-bed to be 6056 feet. It is here called the Gyamo Ngo Chu. A steep climb of 1000 feet from the bridge brought us to the village of Menkong, where we found a small garrison of Chinese soldiers. Apricut and pomegranate trees were growing in the village. Here we found the Tibetans keeping slaves of some race of very small stature (men about 4 feet 8 inches; women about 4 feet 4 inches); they were said to have come from a country which the Tibetans call Tsong, seven days to the south of Menkong. They did not know anything of their own history, they could speak no language but Tibetan, and wore Tibetan dress. They were well treated by their masters. One of the female slaves had a tattoed face. On first reaching Menkong, the Chinese found among the slaves some Chinese whom they liberated, but they allowed the Tibetans to retain slaves who were not Chinese. A mile from Menkong there is a lamasery with about sixty monks, but we were unable to spare time to see it. I was anxious to take an observation for latitude at Menkong, but cloudy weather prevented my doing so. From here Mr. Edgar returned to Batang by the route we had followed thus far together, and I was not to see a white face again until I reached Sadiya. I was sorry to lose my companion, whose experience of travel in the country and knowledge of Chinese were invaluable.

My road lay up the bank of a tributary which joins the Salween at Menkong. There were extraordinarily large numbers of butterflies here,

* Identified by Mr. G. A. Boulenger as Coluber tceniurus, Cope.

+ Prof. Balfour thinks that this is probably a Euphorbia, perhaps E. antiquorum. 
almost all of one species, Neope agrestis. A steep ascent brought me to a pass, the No La $(14,128$ feet). The weather was very cloudy, and I could not see much of the surrounding country, but caught a glimpse of snowmountains to the east. After crossing the range, I found that the streams flowed to a river in a valley lying north-east and south-west. I was unable to determine with accuracy in which direction this river flows; but I think it most probable that it is towards the south-west to join the Irrawady, and that it does not flow into the Salween. The next day, June 17, I had to cross a higher pass, the Tsema La (15,676 feet). On this there was a good deal of soft snow, which caused some trouble to my ponies. The hills around the pass are steep and rocky, the hollows being filled with snow. The weather was cloudy, but I got a brief view of distant snows to the north-west. This pass is closed in winter for animals, but men can always cross it over the snow. After descending from this pass, and following a stream for some miles, I reached a river some 20 yards wide; this is an upper branch of the Irrawady. I asked whether the water did not flow into the Salween, and was told that it did not, but that it went to a country called Lhoka or Tsong. Here the valley of the Irrawady is about 11,500 feet above sea-level. The tops of the bills are grassy, with outcrop of rock, below which is a belt of fir forest, while the bottom of the valley is open grass, on which many ponies and cattle were grazing. Thcre were a few belts of firs or junipers across the grassy valley. I noticed clematis in flower on these trees, and I collected some specimens of Cypripedium orchids (C. lutea and C.tibeticum). The few habitations are very poor rough huts with roofs of pine shingles, and a few fields are occasionally met with, but the crops are uncertain. I heard the call of the large white pheasant (Cressoptilon), but did not see the bird. The saddlecloth commonly used here is a burhel skin, these animals being found on the surrounding hills. On June 18 I stopped at the village of La Gyap, whence I noticed a snow-peak at the head of a valley to the north. I was told that a place called Gula is situated in this valley. After marching for two days up the Irrawady, I came to the foot of a pass, the Tsong La, where I found a circular lake about 150 yards in diameter, to which a border of rhododendrons gave quite an artificial appearance; I shot a partridge, and noticed both blue and yellow poppies. The main branch of the river I had followed for the last two days was here only about a yard wide, and took its rise in the snow-covered hills to the north of the pass. The Tsong La, which was found by hypsometer to be 14,913 feet high, was clear of snow, though there were some drifts on the roadside. The water west of the Tsong La joins with a stream which flows due south, and must be the headwaters of the Tarawan, which passing through Kamti Long joins the Irrawady.

At the Zhasha La, a pass 15,711 feet above the sea, which I crossed on June 20, I left the Irrawady basin and entered that of the Zayul Chu. On the pass there was very little snow actually on the road. After crossing 
it, the road follows down the open valley of a stream which, after about 8 miles, enters a gorge and eventually joins a larger stream at a village called Michi (11,937 feet). This is the place which A. K. visited on April 21, 1882, giving it the name of Rika, which is the name of one of the houses; the village is sometimes called Michi-Rika, but Michi is the commoner name, and I did not hear A. K.'s name for the place until I had made inquiries about it. There are some hot springs here, in one of which I bathed, the temperature being $115^{\circ}$ where the water issued from the ground. My next day's march to Drowa Gompa was along the road followed by A. K. twentynine years previously. At about 6 miles from Michi I noticed a considerable stream bursting from the hillside on the left bank of the river. Drowa Gompa (8746 feet) is a large village of log huts with roofs of shingles held down by stones. The people about here, and to some extent at Menkong, wear an under-jacket of blue cloth edged with red, which gives it the appearance of a kind of uniform. They carry knives in sheaths of wood, one side being open and the knife held in leather thongs, much as do several of the tribes in the Eastern Himalayas; I once bought a sword in a sheath like this from a Mohammedan who was passing through Tibet on his way from Central Asia to Mecca. The people of south-eastern Tibet carry primitive chopsticks formed of a single splinter of bamboo bent double and kept in the sheath with the knife. These people are great snuff-takers. The snuffbox of south-eastern Tibet is of a peculiar kind; a small circular wooden box has a piece of cloth stretched tightly across the mouth, on the top of which the lid fits; the box is tarned upside down and given several sharp taps, which force some of the snuff through the cloth into the lid; this is then removed and the snuff is taken from it. In his table of population A. K. states that there is one lamasery of fifty monks, and twenty-five houses with only five inhabitants; I quite expected that this last statement had been made in error, but I found that, as usual, he was right, and that there were many empty houses. The lamasery now only supports fifteen monks. Finding the people here very friendly, I proposed going to Sanga Chu Dzong, and to this they raised no objection. In this and several other villages I was asked if it was a fact that we were ruled by a woman, and whether it was true that in my country women had much more power than men, who were always obliged to walk, while women were allowed to ride horses.

The road to Sanga Chu Dzong passes up the Zayul Chu in a northerly direction. At Drowa Gompa the river was about 30 yards wide, the water being muddy and of a grey colour. After going up for some miles, I reached a place where the stream narrowed to about 7 yards and flowed partly under the overhanging rocky bank. Here the road crossed to the right bank of the river by a single-span log bridge. At one point a road up a branch of the river leads to a place called Trong-yu. On the left bank, at about 13 miles from Drowa Gompa, there is a fine precipice with a sheer drop of about 1500 feet. The river was a foaming mass of dirty water 
the whole way from Drowa Gompa. There are very few villages. The regular stage, at which I stopped on my return journey, is Loma, famous for the wooden bowls which its inhabitants make. Here I saw potatoes growing, and a kind of $d a l$, called in Tibetan Sanchu, besides barley and peas. The people wished me to go to a place four days' journey to the east, where they said that stags and burhel, with other kinds of game, were very plentiful, but I had not time to do this. As one approaches Sanga Chu Dzong, the road passes through thin forests of fine pine trees in which parroquets * were nesting. Near Sanga Chu Dzong the valley opens out, and there are many scattered farm-houses with much cultivation. This place is called Goschen; and Sanga Chu Dzong, a large group of houses, can be seen on a spur 4 miles to the west. Goschen must be a healthy place, to judge by the number of old people who sit on the roofs of the houses turning prayer-wheels; one intelligent old man told me that he was eighty-two, and had made a pilgrimage to Lhasa sixty years ago. I noticed the horn of a burhel on the roof of a house-the first tangible evidence of the presence of this animal that I had seen for some time. On June 24, at the invitation of the monks, I moved over to Sanga Chu Dzong, traversing the intervening four miles over a plateau covered with scrub, through which two branches of the Zayul Chu cut ravines 500 feet deep. On arrival at Sanga Chu Dzong, I found a crowd of monks, all anxious to get their first sight of a white man. I was housed in a fine brick building close to the monastery. The dzong was deserted and in ruins, as were most of the other houses, but the lamasery was in good repair. There were about seventy monks. In the absence of the abbot, the head monk sent some of the monastery officials to me with a teapot of buttered tea and some boiled rice. I paid a visit to the lamasery, where I was given a meal. There were some fine images in the temple, and a particularly striking row of chortens beautifully ornamented. I also saw two copies of the Tan Jur and one of the Kan Jur, which had been printed at Netang, near Shigatse. In return for their politeness I sent them a photograph of the Dalai Lama, and on my return journey I added one of the Tashi Lama. The valley to the west of Sanga Chu Dzong is well cultivated, and many brick-built farm-houses with roofs of shingles are seen dotted about; the population within a radius of 5 miles cannot number less than five hundred. The river which flows at the base of the spur on which the houses are situated is called the Tsilung Chu. On the most recent maps Sanga Chu Dzong, of which I found the altitude to be 11,693 feet, is placed on a tributary of the Salween, but this is incorrect. The Tibetan Jongpen, who rules this part of the country under the Lhasa Government, had left on account of the arrival of the Chinese. Some months previously he had sent one of his stewards to meet the late Mr. Williamson at Rima; and Mr. Williamson had given this man some Indian tea, which was not used, but was being kept by the monks as a curiosity,

\footnotetext{
* See footnote $(*)$ at the end.
} 
and some advertisement sheets of the Pioneer in which it had been wrapt formed treasures which I was asked to explain. The distance from Sanga Chu Dzong to Lhasa is covered in from twenty to thirty-two days.

On June 26 I left Sanga Chu Dzong. The road passed up the valley of the Tsilung Chu. The bottom of this valley is cultivated for about five miles up-stream, while the hills are covered with a forest of firs, birches and poplars. Opposite the village of Dendon, up a valley to the southwest, I saw a glacier with, as I thought, a stream flowing from it, but I was afterwards to find out that this stream breaks through the range in a surprising manner. The day after leaving Sanga Chu Dzong I crossed the Jo La, a pass 16,307 feet above the sea. This was the first day of clear weather since my departure from Batang. For about half a mile there was deep, soft snow, over which my ponies struggled with great difficulty. Looking back from the pass, I could clearly see Sanga Chu Dzong and the farm-houses of Goschen, and I also had a view for many miles down the valley of the Zayul Chu up which I had travelled. The valleys were all thickly wooded, and the tops of the more distant hills were rocky, with some snow, while those which were nearer to me, and from which several small glaciers emerged, were covered with snow, except where the rocks were too steep to retain it. Owing to the lie of the ground, I could not see anything to the north-west, but after crossing the snow I had a good view. In that direction the country presented an appearance very different from that of the country which I had left; and it was at once evident that its climate is much drier, as the hills were bare of all vegetation except grass and very small shrubs. A stream was seen flowing in a broad open valley. As I was on the top of a high snowy range, I naturally thought that this stream rose in the range and was flowing away from me to the N.W. ; but, on reaching it, I was surprised to find it flowing towards me, and was told that it breaks through the range and comes out at the village of Dendon, where I had previously seen it. On leaving the pass I observed some large snowfields and peaks, quite near, to the south and south-west, and saw the stream flowing into a gorge among rocks, snows, and glaciers. It would be interesting to follow its course through the hills, where some remarkable scenery would be met with, but there is no road. The altitude of the point where the stream enters the gorge must be about 15,000 feet. Some miles from the pass another surprise greeted me, for I came on a small sluggish stream flowing north-west. There is a very flat watershed between the Nagong Chu, which flows past Shiuden Gompa, and the Tsailung Chu branch of the Zayul Chu, which flows past Sanga Chu Dzong. After following this small stream for a short distance, I found that it was reinforced by water from a valley to the south in which there are three glaciers. I camped in a cave which can be recognized by the smoke-blackened entrance. Just before this, a valley from the north leads to the Dama La, over which lies an alternative route from Sanga Chu Dzong, used only when the Jo La is closed by snow. The bottom of the valley here was two miles 
wide and covered with brushwood, in which there were a great many hares and partridges; I also caught many butterflies, including three species of Coleas, and saw a pair of ruddy sheldrakes and some redshanks, which were breeding. Near the Jo La there were also many marmots, one of which was caught by a dog which had attached itself to me. Here I noticed a blue poppy, since identified as Meconopsis rudis, Prain, var. Prattii. I continued on down this valley, which gradually got wider and more broken until I was descending through low hills with a few scattered firs and juniper trees, among which hares swarmed. Finally, I came in sight of the Ngam Tso. This is a lake about four miles long by one mile wide, narrowing at one part, over which the bridge described by $\mathrm{A} . \mathrm{K}$. has been built. The lake is very shallow at the southern end. On the flats which border it are many fields and some farm-houses, while Sbiuden Gompa, a cluster of buildings, is on a hill 400 feet above the water and 13,685 feet above sea-level. I went up to the gompa, and was met by a dirty goitrestricken monk, who combined the duties of head of the lamasery with those of the civil officer of the district of Nagong. From the gompa a large and dirty glacier can be seen descending to the southern end of the lake. The road to the Ata Gang La passes the glacier, and it was by this road that A. K. travelled when he came to Shiuden Gompa after turning back from Rima. Above the lake is a high rocky conical peak. The river which leaves the lake here flows to the west, but I was unable to find out for certain whether it joins the Tsang Po or turns southward to India before reaching that river. In fact, the country between Shiuden Gompa and the Tsang Po is so wild and disturbed that the people of Nagong, the district of which Shiuden Gompa is the capital, never visit it. The women in this part of the country wear a single large turquoise set in silver on the hair, which is plaited in a queue.

I visited the monastery, which holds about seventy monks. It is similar to that at Sanga Chu Dzong, but not quite so fine. The official would only allow me to go in one of two specified directions: I could either go to Chiamdo or return by the way I had come; and I decided to return, as I wished to be back in India by the end of July. Here I succeeded in taking an observation for latitude, and found it to be $29^{\circ} 28^{\prime} 7^{\prime \prime}$. On reaching a stream on my return journey, I was dismayed to find one of my mule drivers above his waist in glacier water, trying to recover a crumpled mass which I recognized as the water-tight tin box containing my small collection of bird skins. There was another box lying in the water, which did not concern me so much. For several days I did my best to dry the skins which, though rather bedraggled, I hoped were not altogether spoilt; the accident was caused by a pony falling off a rickety bridge. Passing Drowa Gompa again on July 3, I arrived the same evening at Chikung, where I found a Chinese garrison of soldiers under an officer. We exchanged visits, and he was most friendly, treating me to a bottle of champagne. The soldiers besieged me for medicine, of which I distributed some 
quantity, treating each case according to the instructions in 'Hints to Travellers'; I sincerely hope that no harm resulted.

The road I followed on this and the two following days down to Rima was that along which A. K. had travelled in 1882. I found an Indian slave with the Chinese at Chikung. He had been captured by the Mishmis, who sold him to the Tibetans, but the Chinese had released him; I offered to take him with me to India, but he would not come. The road from Drowa Gompa to Rima follows the Zayul Chu. There is very little cultivation, though the soil appears to be adapted for it. At one point, opposite to the village of Dabla, there is a fine, almost sheer face of rock, standing up about 1000 feet above the left bank of the stream. The roadway is very bad; in places galleries are built round the cliffs, and in others sticks have been fixed horizontally across the smooth rocks to give ponies a foothold. Near Rima the valley widens out considerably, and a large river, the Rong To $\mathrm{Chu}$, joins the Zayul $\mathrm{Chu}$ from the north-west. The combined river is called the Ngo Chu by the Tibetans. About a mile north of Rima is the village of Shika. This used to be the headquarters of the Tibetan officials, while Rima was the village in which the local peasants lived. I saw many rice-fields here, and also maize, while apricot trees were bearing unripe fruit; there were a few Chinese soldiers who had grown various Chinese vegetables successfully.

I reached Rima on July 5. I was much disappointed to find that boots were unknown here, as I had hoped to be able to replace mine, which were quite worn out. I took two observations for altitude with the hypsometer, and found it to be 4839 feet; A. K. made it 4650 feet. Snow falls here in winter; the temperature in the shade was $91^{\circ}$ at 4 p.m., and in a very open room by a window the minimum was $71^{\circ}$ at night.

The inhabitants of Rima are different from those of the other parts of south-eastern Tibet through which I had just passed. They cut their hair short and do not wear a queue; elsewhere in south-eastern Tibet the people never smoke, though they take quantities of snuff, but at Rima tobacco is both grown and smoked. The inhabitants of Rima are very much cut off from the rest of Tibet; they never make the usual pilgrimage to Lhasa or other holy places, and, although professedly Buddhists, are very lax in their religion; when I was in pursuit of Takin I saw a man sacrificing a fowl in order to bring him luck. The form of marriage among them is that "by capture"; the bridegroom goes with his friends to the house of the bride, where the men of both parties quarrel and fight for a time; the quarrel is then made up, all feast together, and the couple are considered to be man and wife. I had noticed that the people of Sanga Chu Dzong and at several other places wore coats made of the skins of gooral of a foxy-red colour, which were said to come from the neighbourhood of Rima. I made inquiries about this, and was told that these animals were plentiful in the hills down-stream from Rima.

One day's march down the river brought me to Kahap, which is called 
Kanau on the R.G.S. map of 'Tibet. Mosquitoes and biting flies were troublesome here. Ponies cannot travel on the road down from Rima, as in many places the track climbs over cliffs and up notched logs, near which a rope of creepers is usually fastened to help the traveller. From Kahap I went two days' journey into the hills to the east over awful roads, and here found a hot spring where a herd of about three hundred Takin (Budorcas taxicolor) come every night and morning to drink. I returned to Kahap after having shot six of them. At one place in this valley I crossed drifts of old dirty snow at an altitude of less than 10,000 feet. A pass at the head of this valley, between 30 and 40 miles from Kahap, leads to a country which the Tibetans call Cho, where a people similar to the Mishmis live. From Kahap I marched to Tinne, where a rope bridge spans the Lohit river. The river was about 80 yards wide, and very rapid and muddy. At Tinne I met some Mishmis, from whom I heard for the first time of the murder of Mr. Williamson and Dr. Gregorson. Plantains and tobacco were grown at this village.

From Tinne I travelled down the Lohit, passing through the Mishmi country. At a village called Krang, about 22 miles below the great bend in the river, I lost my compass, and was therefore obliged to discontinue the route survey which I had kept up since leaving Yen-ching on the Mekong river. The Mishmis are great smokers; their pipes are of bamboo, the tobacco being grown locally and dried in the sun; they also smoke a great deal of opium, which is mixed with sacking and smoked in a roughly made bamboo pipe. The Mishmi carries a flint and steel somewhat similar to that used by the Tibetans; pine torches afford his only artificial light, and towards the end of our marches my coolies used to search among the driftwood on the river-bank for a log of resinous pine from which to make them. The chief article of food in the country is maize, but I also got a few sweet potatoes and unripe plantains, which, when cooked, are quite an eatable vegetable. Every evening a mist about fifty feet thick used to hang above the water, and when the road dropped into this, I noticed a fall in temperature, while on rising out of it I felt as though entering a hot-house. I reached Tashalun, the Mishmi village nearest to the Indian frontier, on July 29. Here, to my disappointment, I found that the usual road to Sadiya was impassable owing to the swollen condition of the river, and that I should be obliged to cut my way through the jungle at the foot of the hills where the streams were smaller. I spent a day in this village, as the coolies had to prepare food for several days in advance. The chief house of the village was a very long narrow bamboo building, raised about four feet from the ground, and divided into cubicles, in each of which one family lived. A fire was lit in the middle of each cubicle, and three long logs, which met in the fire, were gradually moved in as they burnt away, the parts of them lying across the room being used as pillows. Some of the Mishmi villages further into the hills were surrounded by a bamboo palisade with sharpened spikes on the door. The Mishmis cover the walls of their houses with the skulls of cattle and other animals; the house in which I stopped at Tashalun

$$
\text { No. IV.-APRIL, 1912.] }
$$


showed over seventy such skulls, all, with one exception-a deer-being those of domestic animals. Eight days' travelling from Tashalun brought me to Sadiya. I was obliged to cut through a virgin forest for most of the way, and to ford many rivers; but sometimes my Mishmi coolies would fell a tree to bridge a small deep river. At one place I only made a quarter of a mile after cutting through the jungle for an hour and a half. Leeches were very troublesome; I have never seen them worse. I saw tracks of many varieties of game, including elephant and buffalo, and at one of my camps in the hills the coolies asked. me to sleep with my rifle at hand, as they had heard a tiger prowling round. On my last day's journey into Sadiya, I voyaged down the river in a narrow dug-out canoe. At Sadiya I was the guest of Mr. Dundas and Captain and Mrs. Robertson.

Goitre is a very common disease all over south-eastern Tibet, and is not uncommon among the Mishmis. At the time of year at which I was travelling, the weather was most unfavourable for survey work. Clouds nearly always obscured the higher hilltops, and rain fell frequently, while in winter many of the passes are closed by snow. Consequently, this must always be a difficult country to survey. In July and August the minimum temperatures at night in the Mishmi country varied between $61^{\circ}$ and $76^{\circ}$. I found the Mishmis difficult to manage, but, luckily, had some opium with me, for which drug a Mishmi will do a great deal. I carried no tent, but in Tibet I usually slept in a house, and in the Mishmi hills the people rigged me up shelters of plantain leaves. A word in praise is due to my Tibetan servant, Putamdu, who, having on my summons gone down to Calcutta, had been shipped out to China by Thomas Cook, and accompanied me throughout my journey from Peking to Sadiya. I brought back a small collection of about sixty skins of birds,* with the eggs of several species, and the skins of a few small mammals. $\dagger$ I had also about two thousand specimens of butterflies, + besides two hundred moths and a few other insects.

The latitude of Shiuden Gompa was determined with a 6 -inch sextant, and all heights were taken by hypsometer. I am indebted to the Royal Geographical Society for the loan of these instruments, and to the Survey of India for their kindness in working out the results of my observations.

* Mr. Ogilvie Grant says that special mention may be made of the rare Koslow's Scimitar-babbler (Babax koslowi) and a small brownish warbler or chiff-chaff, believed to be Phylloscopus homeyeri, neither of which species was represented in the Natural History Museum. Other rare species are Lord Derby's parroquet (Palceormis derbyensis) and Széchenyi's pheasant grouse (Petroophasis szechenyii), with other game birds. Among these last he has identified five pheasants (Crossoptilon thibetanum, Thaumalea amherstice, Phasianus elegans, Ithagenes geoffroyi), and a Tragopan; a partridge (Perdix sifanica); and a snowcock (Tetraogallus tibetanus).

$\dagger$ Mr. Oldfield Thomas states that two of the mammals proved to be new-a mole-rat (Myospalax) and a mouse-hare (Ochotona). These have been named, respectively, $M$. baileyi and $O$. roylii chinensis.

I The working out of the collection of butterflies is not yet completed, but it seems probable that it comprises from 150 to 170 different species, of which perhaps a dozen or so may prove to be new. 
I add an itinerary of my march from Wan-Hsien, on the Yangtse, to Sadiya :-

\begin{tabular}{|c|c|c|c|c|c|c|c|}
\hline \multirow{2}{*}{\multicolumn{4}{|c|}{ Marches. }} & \multirow{2}{*}{ Dates. } & \multicolumn{2}{|c|}{ Days. } & \multirow{2}{*}{ Miles. } \\
\hline & & & & & Marching. & Halting. & \\
\hline \multicolumn{2}{|c|}{ Wan-Hsien to Chengtu } & $\cdots$ & $\cdots$ & April 9-22 & 14 & - & 400 \\
\hline Halt at Chengtu & $\ldots$ & & $\ldots$ &, $23-26$ & - & 4 & - \\
\hline Chengtu to Tachier & & $\ldots$ & $\ldots$ & April 27 to May 9 & 13 & - & 255 \\
\hline Halt at or near I & ien & $\ldots$ & $\cdots$ & May $10-18$ & - & 9 & - \\
\hline Tachienlu to Ho-ko & or $N$ & chuk & $\ldots$ & ", 19-23 & 5 & - & 80 \\
\hline Halt at Ho-kou & $\cdots$ & $\cdots$ & $\cdots$ & "24 & 一 & 1 & - \\
\hline Ho-kou to Litang & $\cdots$ & $\cdots$ & $\cdots$ &,$\quad 25-28$ & 4 & - & 80 \\
\hline Litang to Batang & $\cdots$ & $\cdots$ & $\cdots$ & May 29 to June 2 & 5 & - & 145 \\
\hline \multicolumn{4}{|c|}{ Total-Wan-Hsien to Batang } & April 9 to June 2 & 41 & 14 & 960 \\
\hline Halt at Batang & $\ldots$ & $\cdots$ & $\cdots$ & June $3-5$ & - & 3 & - \\
\hline Batang to Menkong & $\ldots$ & $\ldots$ & $\ldots$ &,$\quad 6-15$ & 10 & - & 174 \\
\hline Menkong to Drowa & $\mathrm{mp}$ & & $\ldots$ & , 16-21 & 6 & - & 93 \\
\hline Drowa Gompa to $\mathrm{S}$ & den & mpa & $\ldots$ & , $22-27$ & 6 & - & 80 \\
\hline Halt at Shiuden & npa & $\ldots$ & $\ldots$ &,, 28 & - & 1 & - \\
\hline Shiuden Gompa to & & $\cdots$ & $\ldots$ & June 29 to July 5 & 7 & $\overline{1}$ & 123 \\
\hline $\begin{aligned} \text { Halt at Rima } & \ldots \\
\text { Rima to Sadiya } & \ldots\end{aligned}$ & $\cdots$ & $\cdots$ & $\begin{array}{l}\cdots \\
\ldots\end{array}$ & $\begin{array}{l}\text { July } 6 \\
\text { July } 7 \text { to August } 7\end{array}$ & $\overline{28}$ & $\begin{array}{l}1 \\
4\end{array}$ & $\overrightarrow{285}$ \\
\hline \multicolumn{3}{|c|}{ Total-Batang to Sadiya } & $\ldots$ & June 3 to August 7 & 57 & 9 & 755 \\
\hline \multicolumn{4}{|c|}{ Grand total-Wan-Hsien to Sadiya ... } & April 9 to August 7 & 98 & 23 & 1715 \\
\hline
\end{tabular}

\section{THE CLIMATIC LIMITS OF WHEAT CULTIVATION, WITH SPECIAL REFERENCE TO NORTH AMERICA.*}

By J. F. UNSTEAD.

THe object of this inquiry is to determine the limits of wheat cultivation which are set by climatic conditions, and to apply the conclusions obtained to the special case of North America. At the present time the actual limits are seldom set by physical controls. For example, such economic factors as facilities for transport and the supply of labour are the chief determining factors in the north-west of Canada, and the construction of railways and the increase of settlers will at once be followed by an extension of the wheat area. Such extensions, however, tend to make the actual and ultimate limits coincide, and the latter are determined by physical controls. The ultimate limits cannot be estimated in any definite and final manner, for they are subject to change as man obtains a greater knowledge of agricultural methods, including not only management of the soil and selection of the best times for farming operations, bat also tho breeding of new varieties of plants specially adapted to conditions found

* Thesis approved for the degree of Doctor of Science (Economics) in the University of London. Research Meeting, March 21, 1912. Map, p. 420. 


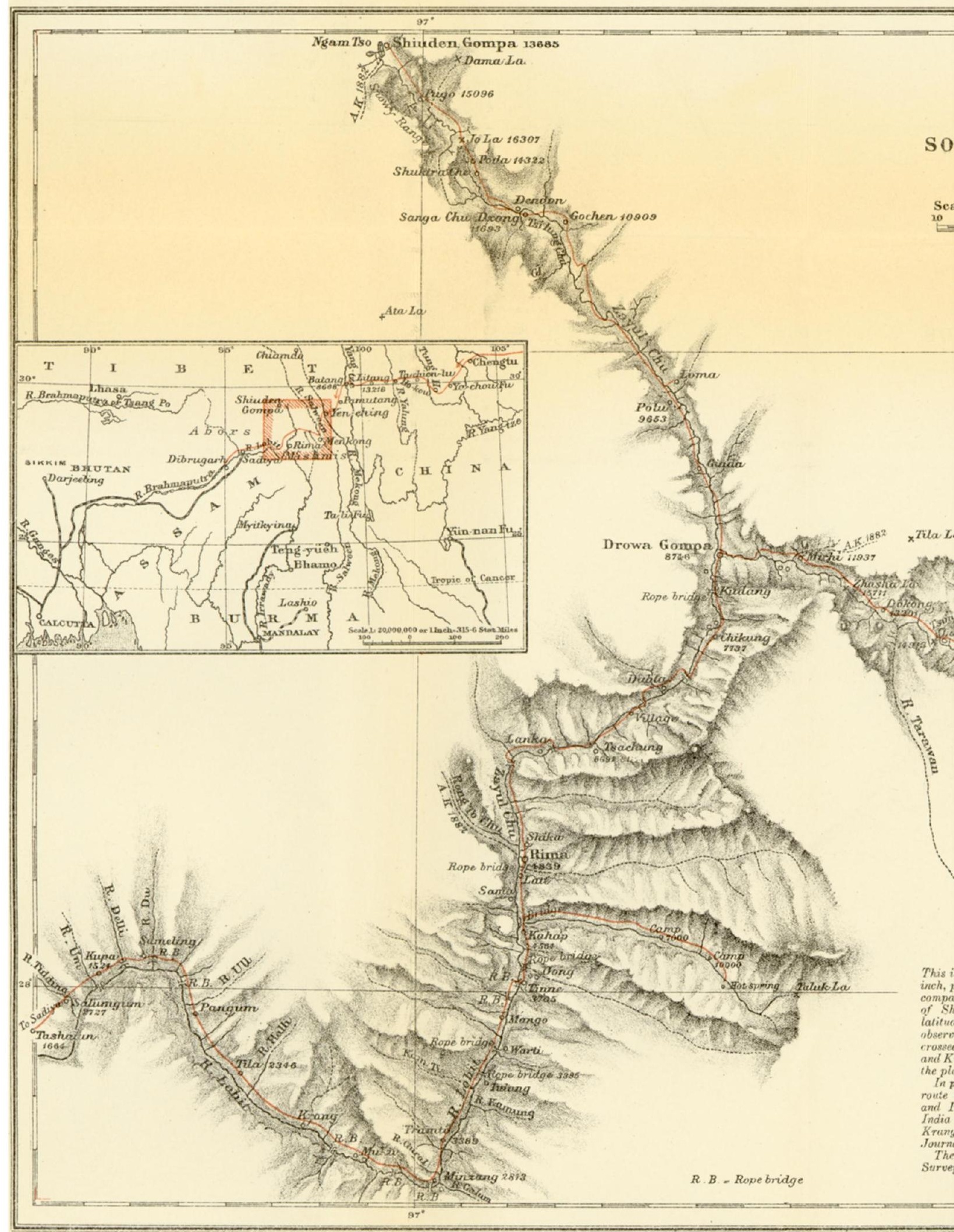

Published by the Royal Geographical Socieb;

This content downloaded from 128.104.46.206 on Mon, 20 Jun 2016 17:17:00 UTC All use subject to http://about.jstor.org/terms 
